
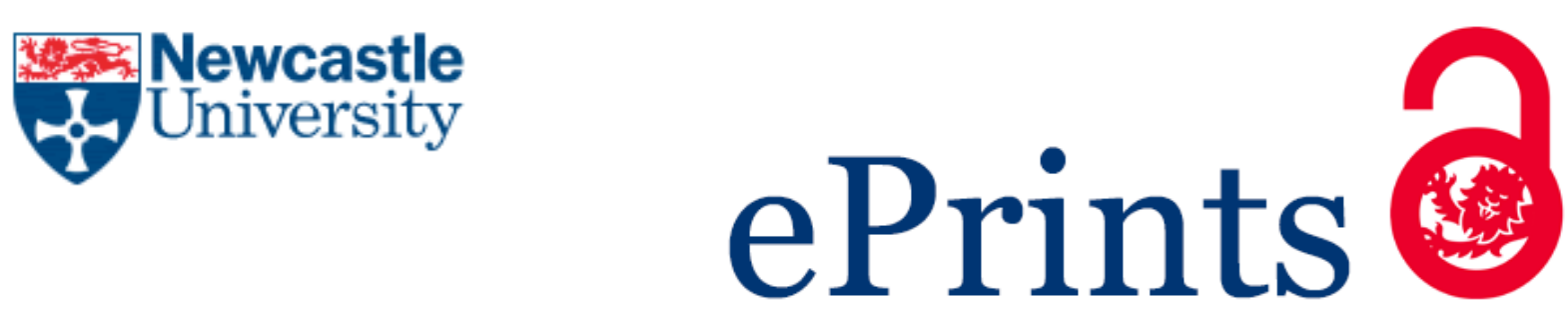

Steccolini I, Jones M, Saliterer I.

Introduction: Governments and Crises.

In: Steccolini I; Jones M; Saliterer I, ed. Governmental Financial Resilience: International Perspectives on How Local Governments Face Austerity. Emerald, 2017, pp.1-16.

\title{
Copyright:
}

This is the authors' accepted manuscript of a book chapter that was published in its final definitive form by Emerald, 2017.

URL to article:

http://www.emeraldinsight.com/doi/book/10.1108/s2053-7697201727

Date deposited:

$29 / 06 / 2017$ 


\section{Introduction: Governments and Crises}

Governments are no strangers to dealing with crises. On the contrary, it could be said that one of central roles of any government is to absorb, navigate and mitigate them. However, crises are not straightforward to solve, as they do not respect timescales, are unexpected and disruptive and tend to be dynamic and chaotic in nature (Boin and 't Hart, 2003). Indeed, they are a challenge to governments, which may even make mistakes along the way in their attempts to deal with them (Peters, 2011).

While crises and shocks are often described as one-shot, unique events, it has been observed that they are increasingly becoming "routine", requiring governments to be constantly ready to tackle with them, as they are left with the ultimate responsibility to manage and cope with them. As such, there have been increasing claims for studying how governments face crises so as to learn important lessons for the future (for example, Boin and Lodge, 2016). There have also been calls to ensure that the wider complexities and nuances of responses to crises are explored, not only focusing on political and policy perspectives, but also allowing a greater understanding of institutional effects and organisational practices, together with how these are changed and implemented and the outcomes they deliver (Boin et al, 2009; Peters, 2011; Lodge and Hood, 2012). As such, a multi-disciplinary approach may be required to give a fuller understanding of crisis responses within and across governments (Grossi and Cepiku, 2014).

The recent global financial crises, and the ensuing context of austerity, representing another important and contemporary crisis that governments have had to face, can provide an interesting opportunity for learning lessons of general relevance on how governments cope with difficulties and unexpected events. Whereas much of the preceding empirical literature on crisis responses has been focused on discrete events (such as natural disasters or terrorist attacks), and is therefore very localized and not necessarily generalizable, the global financial crisis and austerity period offer the opportunity to examine responses from a large population of essentially similar organisations from a wide range of countries, all facing a similar (though not identical) set of circumstances. 
This book shows how local governments in 11 countries responded to the recent crises and austerity by shedding new light on the role of contextual- and policy- related conditions as well as the internal capacities and conditions that may influence such responses and, ultimately, performance. In spite of national governments having attracted most scholarly attention (for example, Peters, 2011; Peters et al., 2011; Kickert 2012; Lodge and Hood, 2012; and Raudla et al., 2013), local governments are often the residual bearer of the impacts of crises and shocks, and have been significantly affected by recent crises and austerity (Barbera et al., 2016; Steccolini et al, 2015). Moreover, while traditional literature on crises, austerity, fiscal stress, cutback management and financial difficulties has focused on the contextual conditions and the organizational actions and reactions to difficulties, this book also considers the role of internal pre-existing conditions and organizational capacities in affecting such responses. In doing so, it adopts the conceptual perspective of financial resilience. The concept of resilience, which can be defined more generally as the ability to "learn how to do better through adversity" (Wildavsky, 1988: 2), can contribute to the adoption of a long-term and lifelong perspective on organizational ability to cope with difficult times. Moreover, a resilience perspective can help overcome the current traditional focus of management approaches to efficiency, stability and control (Shaw, 2012; Leach, 2008) and point to the likely importance of flexibility and adaptation, or the enduring capacity to absorb shocks (Hood 1991; Dalziell and McManus 2004; Scotti Petrillo and Prosperi 2011; Breen and Anderies 2011; Pain and Levine 2012).

This chapter sets the scene for the book and in so doing it introduces and explores a number of issues relevant to understanding the following chapters. The remainder of this chapter considers the need to examine the financial crises and austerity period and introduces the concept of financial resilience. It proposes a first framework, where financial resilience is viewed as a dynamic combination of interrelated dimensions which are seen as being at the same time the antecedents and the results of their interactions with the external context and shocks. The possible dimensions of resilience from the literature (in terms of robustness, recovery ability, awareness and flexibility) are identified and translated into a first conceptualization of financial resilience. This seeks to show how local authorities' capacity to anticipate, absorb and react to shocks that affect their finances over time, can be considered to be a dynamic combination of interrelated 
dimensions, namely: financial shocks, vulnerability, anticipatory capacity and coping capacity. Finally, we discuss the importance of the global financial crisis and associated austerity to the study of resilience before focusing on the impact that each has had on local government.

\section{Studying crises and austerity in the public sector}

Crises have been the subject of enduring interest in public administration and public policy research. While a variety of approaches and standpoints have been adopted in the study of governmental responses to crises, at least three different streams of research can be identified from the literature that are considered below.

The first stream has developed at the intersection of public management and organization theory (e.g. Andrews, Boyne, and Walker 2013; Boyne and Meier 2009; Meier and O'Toole 2009; Meier, O'Toole, and Hicklin 2010; O' Toole and Meier 2010), and focuses on organizational reactions to shocks, threats, uncertainties and turbulences. This predominantly quantitative research stream highlights the role of the overall management capacity in coping with shocks, and has pointed to the need to further explore such capacity and its dynamic properties over time (Boyne and Meier 2009).

The second stream of literature has developed at the intersection of public policy and organizational studies and has been more traditionally focused on understanding how policy makers respond to major crises (such as natural and man-made disasters and terrorist acts) and the effectiveness with which they link to the administrative processes that underpin crisis management and disaster recovery systems (Boin and ' $t$ Hart, 2010). More recently, this literature has focused on changing societal conditions that give crises transboundary characteristics, allowing them, as with the financial crisis, to wickedly cut across geographic boundaries and policy sectors (Boin and Lodge, 2016).

The third stream of literature is more focused on financial management and accounting. There is a long standing academic interest in financial crises and fiscal stress in public sector financial management literature (Behn 1980; Greenwood 1981; Hood and Wright 1981; Levine 1978, 1979; Levine and Posner 1981; Schick 1980). Building on this literature, studies of how governments tackled the fiscal crisis and austerity worldwide 
have been developed (Baker 2011; Cepiku and Bonomi Savignon 2012; Dougherty and Klase 2009; Klase 2011; Sacco et al. 2011; Scorsone and Plerhoples 2010; Raudla, Savi and Randma-Liiv 2013; West and Condrey 2011), providing detailed accounts and classifications of reactions to the crisis and austerity, therefore ensuring an accumulation of contextual and descriptive knowledge on response strategies. Less attention appears to have been devoted to austerity and crises in the accounting literature, with a few notable exceptions (see Bracci et al. 2015; Hodges and Lapsley, 2016).

These streams of research offer a mix of empirical and theory building approaches and while each stream is valuable in its own right, they do not on their own capture the dynamic and inter-related nature of crises responses, and tend the underplay the complex and interrelated nature of capacities that underpin strategic responses, something which a resilience view can help in understanding.

\section{An alternative conceptual lens: resilience}

Since its origins in the field of physics and ecology (see Davoudi and Porter, 2012), the concept of resilience has been adopted and extended to other disciplines, including public policy, urban planning, disaster and crisis management (Wildavsky, 1988; Comfort 2002; Vale and Campanella 2005; Pain and Levine 2012; Boin and Van Eeten 2013; Reid and Botterill 2013; Wukich, 2013). In the next sections we review relevant organizational literature on resilience, both from the public and the private sector, and then advance the case for conceptualizing financial resilience.

\section{Organizational resilience: definitions and dimensions}

The concept of resilience refers to both organizational capacity to recover from crises and reduce risks (Boin and Van Eeten 2013; Holling 1973; Pickett, Cadenasso, and Grove 2004; Shaw 2012; Sutcliffe and Vogus 2003; Vickers and Kouzmin 2001; Wukich 2013) as well as the ability to "keep operating even in adverse 'worst case' conditions and to adapt rapidly in a crisis" (Hood 1991, 14). The former view focuses on recovery, staying robust under enormous stress, and the efficiency of bouncing back to equilibrium (Altintas and Royer 
2009; Bhamra, Dani, and Burnard 2011; Boin and McConnell 2007; Coutu 2002; Davoudi 2012). In this perception of resilience, financial and personnel capacity, and the activities of an organization, are aligned to build slack that cushions and absorb shocks (Huy and Mintzberg 2003; Meyer 1982), presumably with the aim to resist and survive. The latter, i.e. the evolutionary approach to resilience (Davoudi 2012; Hamel and Välikangas 2003; Pike, Dawley, and Tomaney 2010), emphasizes the capacity to reorganize as a response to, or in anticipation of, disturbances (Martin and Sunley 2006). This view interprets resilience as a continually changing process and goal, and as a case of becoming rather than being; interpreting it as part of a pathdependent trajectory. In this view, organizations become resilient not despite of distress or decline, but in anticipation or because of it (Sutcliffe and Vogues 2003). Here, resilient organizations recognize a window of opportunity in disruptions and alter or reinvent their strategies before circumstances force them to do so (Gunderson and Holling 2002; Hamel and Välikangas 2003; Holling 1986).

Resilience is multifaceted, and can work across organisations in a number of ways including (1) situation awareness, the extent to which an organization and/or relevant actors have a clear understanding of the organizational operating environment, including opportunities and potential crises as well as their trigger factors (2) the management of key vulnerabilities, to reduce the susceptibility of the organization to disturbances, and (3) adaptive capacity, the set of available resources and competencies that give the ability to adapt to disturbances (McManus et. al. 2007; Nelson, Adger and Brown 2007). In general these are discussed in broad terms, with a variety of meanings and there have been calls in the public administration literature for empirical studies to give more depth on these facets of resilience (Boin and Van Eeten 2013). This book seeks to add to this clarification.

Four main dimensions of resilience are generally identified in organizational literature: robustness, recovery ability, awareness and flexibility.

Robustness is the capacity to maintain "system performance in spite of exogenous and endogenous uncertainty and change" (Anderies et al., 2004; Anderies, 2006; Anderies et al., 2003; Anderies et al., 2007; Janssen and Anderies, 2007; Janssen et al., 2007; Martin-Breen and Anderies, 2011, p. 41; Burnard and Bhamra, 2011). Robust organizations are enduring and resistant to change (Carmeli and Markman, 2011) and 
have a high degree of tolerance to disturbances (Mamouni Limnios et al., 2014). While being plausible in the short term, robustness may not be suitable in the long term as disturbances may destabilize the organization and the need for some changes may arise (Martin-Breen and Anderies, 2011).

Recovery ability (Kendra and Wachtendorf, 2003; Sutcliffe and Vogus, 2003; Välikangas and Romme, 2012; Whitman et al., 2013), is the capacity to restore functionality in a timely way. This capacity can be linked to the presence, within the organization, of adaptive behaviors, bricolage skills, team working and sharing of the decision making power (Mallak, 1998), as well as organizational learning and openness to develop new capabilities (Lengnick-Hall et al., 2011).

Awareness (or preparedness), characterizes those organizations that are able to manage future challenges and to anticipate crises (McManus et al., 2007; Fleming, 2012; Linnenluecke and Griffiths, 2013; Whitman et al., 2013), for example through their planning capacity and practices (McManus et al., 2007; Erol et al., 2010; Fleming, 2012; Linnenluecke and Griffiths, 2013; Whitman et al., 2013) or their organizational proactivity (Erol et al., 2010; Starr et al., 2003).

Finally, flexibility represents the ability to change after external and/or internal shocks (see Wildavsky, 1988; De Oliveira Texeira and Werther Jr., 2013; Skertich et al., 2012; Välikangas and Romme, 2012; Pal et al., 2014; Ates and Bititci, 2011). Being flexible means being able to change as soon as disturbances arise (Ates and Bititci, 2011, thus to renew over time through innovation processes (De Oliveira Texeira and Werther Jr., 2013; Reinmoeller and van Baardwijk 2005), to continuously reconfigure intellectual, financial, technological and human resources (De Oliveira Texeira and Werther Jr., 2013; Pal et al., 2014), business model and strategies (, behaviours (Välikangas and Romme, 2012), dynamic competitiveness (Pal et al., 2014), as well as to promote creativity within the organization (McManus et al., 2007).

Resilience literature has tended to adopt a predominantly prescriptive and normative stance, highlighting the need for more empirical research (see, for example, Boin and Van Eeten 2013, 430; Wukich 2013) as well as for the development of measures to assist in the operationalization of resilience (Dalziell and McManus 2004; Reid and Botterill 2013). The literature on resilience in the public sector has often focused on public policy issues (for example, Walker et al. 2006; Maguire and Cartwright 2008; Seville 2009; Shaw 2012; Bailey 
and Berkeley 2012; Reid and Botterill 2013) or crisis management (for example, Rosenthal et al., 1989, 2001; Boin, 2009; Vale and Campanella 2005; Comfort 2002; Boin and Van Eeten, 2013; Wukich, 2013). However, much less attention has been devoted in this literature to how governments face and absorb external shocks affecting public finances, i.e., financial resilience.

\section{Towards a conceptualization of financial resilience}

In recent years there has been a resurgence of scholarly interest towards governmental financial crises and stress. This has been due to a number of factors, including not only the sovereign debt crises, but also the increasing number of bankruptcies in local authorities and, more generally, the conditions of cutback management that are striking many public sector organizations. On the one hand, contributions have been developed on how to predict and detect fiscal distress (for example, Hendrick, 2004; Kloha et al. 2005; Trussel and Patrick 2009; Maher and Deller 2010; Garcia-Sanchez et al. 2012). On the other, literature is growing on how austerity is being tackled by governments (Hendrick, 2011; Klase 2011; Dougherty and Klase 2009; Bozeman 2010; Maher and Deller 2010; Pandey 2010; Scorsone and Plerhoples 2010; Baker 2011; West and Condrey 2011; Sacco et al. 2011; Cepiku and Bonomi Savignon, 2012; Raudla et al., 2013). However, this literature tends to provide classifications of reactions to crises, often leaving the organizational conditions, capacities and histories, which may affect such reactions, in the background. Moreover, as Bozeman (2010) points out, focusing only on decline and cutback management may cause scholars to miss an important opportunity to build new theories adopting a longitudinal and strategic view on the whole life-cycle of public organizations.

This is even more important as we are entering an era of cyclical volatility characterized by rapid reoccurrence of cycles of decline (Pandey 2010). Thus, the austerity period appears particularly suited to study organizational responses to shocks and crises not only in a specific time and space, which may be an important aim per se, but also to capture patterns of behaviors that are of more general relevance to public administration literature and bear general significance for organizations going forward. This requires observing not only actions and reactions to crises and shocks, but also to better clarify how pre-existing 
conditions and capacities affect decisions and actions. An interesting effort in this direction is offered by Meier and J. O'Toole (2009) and Meier et al (2010) studies, based on a set of US public school districts, on how shocks impact on performance and how public managers can handle and mitigate environmental shocks. However, these studies are not aimed at exploring in-depth the capacities and conditions that affect organizational responses.

In the light of these considerations, the resilience concept may further prove relevant in several respects. First, it can contribute to the adoption of a long-term and lifelong perspective on organizational capacity to cope with difficult times. Second, it can help to overcome the current traditional focus of management approaches on efficiency, stability and control (Shaw 2012; Leach 2008) and point to the likely importance of flexibility and adaptation, or the enduring capacity to absorb shocks (Hood 1991; Dalziell and McManus 2004; Scotti Petrillo and Prosperi 2011; Breen and Anderies 2011; Pain and Levine 2012).

At the same time, the financial management arena appears to be suited for studying resilience at a time where fiscal stress and shocks are of particular significance. No conceptualization of financial resilience has been provided so far. In response to calls for empirical analyses and operationalizations of resilience, this book focuses on a specific facet of resilience, ie, financial resilience, and proposes a first conceptualization of it as the capacity of a government to face and absorb external shocks affecting public finances.

\section{A framework for exploring financial resilience}

This section develops the preceding discussion of the literature into a framework for exploring financial resilience. To this aim, the dimensions generally identified in the literature need to be considered in a finer grained way and need to be observed in terms of their dynamic evolution over time. Financial resilience of local governments, i.e. their capacity to anticipate, absorb and react to shocks affecting their finances over time, can be considered to be a dynamic combination of four interrelated dimensions, namely: financial shocks, vulnerability, anticipatory capacity and coping capacity.

\section{Financial Shocks}


These represent any unexpected external or internal events that have significant and long lasting impacts on the finances of an organization, negatively affecting its financial position and possibly ultimately threatening its survival. Shocks could have a direct financial impact, such as a reduction in transfer payments from central government or the failure of a PPP/PFI contract, or, could have a more indirect relationship in the case of demographic changes, natural disasters or emergencies, or changes in government policy, the consequences of which may lead to a financial impact in terms of increased demands for expenditure or reduced income.

\section{Vulnerability}

From a resilience perspective, vulnerability is interpreted as the level of exposure to a specific shock. A range of external and internal factors could contribute to this including dependence on uncertain revenue bases, rigidity of expenditure, uncertain or reducing resource transfers from higher governmental levels and the degree of diversification of sources of income. Furthermore, high levels of debt, or a reliance on PPP/PFI schemes may lead to non-controllable liabilities or financial risks. . The general level of vulnerability can be compared before and after a crisis event by identifying where action has been taken to reduce or mitigate exposure, something which the authors consider in relation to the countries considered in each chapter.

\section{Anticipatory and Coping Capacities}

Anticipatory capacities refer to the availability of tools and capabilities in place, or built up over time, that enable organisations to better identify and manage their vulnerabilities and to recognize potential financial shocks before they arise, as well as their nature, likelihood, timing, scale and potential impacts. These tools and capabilities could include internal and external monitoring processes and might occur within a mediumterm financial planning framework or be built up incrementally over time. 
Coping capacities refer to resources and abilities that allow shocks to be faced and vulnerabilities to be managed. Dealing with shocks may require reliance on different coping capacities, namely buffering capacity (i.e., the ability for absorbing shocks), adaptive capacity (i.e., the ability for implementing incremental changes) and transformative capacity (i.e., the ability for taking paths of more radical changes) (see also Béné et al. 2012; Darnhofer 2014; Davoudi, Brooks, and Mehmood 2013; Keck and Skadapolrak 2013). Buffering capacity represents more traditional budget management techniques such as the use of reserves, virement and slack resources (contingencies) to absorb short-term, one off and minor financial shocks. It may also include increases in tax revenues or short-term reductions in programme expenditures or deferring expenditures to later periods. Adaptive capacity represents latent competences and experiences that can be drawn on for adjusting organizational activities, while not jeopardizing the overall status quo. These include capacities that promote the ability to innovate around the edges or find new ways of doing the same or similar things. Transformative capacity, enabling more radical fiscal or organizational changes, represents a higher order capacity and may not be present at the start of a crisis, but become a feature afterwards.

\section{The context of the book: global financial crisis and austerity}

The global financial crisis, which began with the collapse of the sub-prime banking sector in the United States in 2007, reverberated around the financial markets of the world, leading to an international economic crisis and ultimately resulting in significant fiscal crisis for national governments (Kickert, 2012). The impact of the crises were severe. Wolman (2014) reported that in OECD countries for example, the average annual rate of GDP real output growth was $3.4 \%$ between 2000 and 2007, but only $0.9 \%$ in 2007/08. Between 2007 and 2011 this dropped to $0.5 \%$ with some countries experiencing negative growth rates during this period. This was accompanied by increases in unemployment rates (from 5.6\% for OECD countries as a whole in 2007 to 8.1\% in 2009) as well as initial fiscal stimulation policies and bailout packages for the banking sector, all of which put additional strain on national budget deficits and borrowing positions. For example, there was a fiscal deficit across the OECD area of $7.9 \%$ of GDP in 2009 with the OECD predicting that in 2011 , as the crises unwound, gross government debt would exceed 100\% of GDP (OECD-SBO, 2011). The dire economic and 
fiscal consequences that followed, triggered a period fiscal and economic policy making that has come to be generally referred to as the era of austerity.

Despite its global reach however, the impact of the global financial crisis was not felt equally by countries across the world, with some such as the PIIGS countries of Portugal, Italy, Ireland, Greece and Spain being significantly affected, while others such as Sweden experiencing very little impact (OECD-SBO 2011). Similarly, austerity as a policy response has taken on different forms in different countries, whether this be fiscal consolidation through reduced expenditure and increased taxation, an opportunity to shrink the size of the state itself or through some intermediate approach (Heald and Hodges, 2015). For some countries such as the UK, austerity was adopted voluntarily, whereas for others such as Greece, austerity was an external requirement of supra-national bodies such as the International Monetary Fund (IMF) and the European Union (EU). For EU states in the European Monetary Fund (EMU) responding to the crisis was further complicated through the ongoing enforcement of the growth and stability pact that preceded the onset of the financial crisis. Drawing on crisis management literature, Peters (2011) observes a range of responses in play across countries in response to the financial crisis including the centralization and politicization of decision making (although for some countries such as Slovenia a more consultative approach was introduced), as well as governments using the crisis as an opportunity to drive through changes that would previously have been impossible (austerity in the UK for example) or to reinforce their approaches to policy and governance.

The global financial crisis, and the ensuing era of austerity, bears all the hallmarks of a crisis as we have described them in this chapter. As such it is a highly suitable situation around which to frame a study of resilience, and financial resilience in particular. The international yet disparate reach of the crises and the lack of uniformity of the subsequent policy responses means that an international comparison of the impact and reactions to austerity is timely.

\section{The crisis, austerity and local governments}


Within the national context, sub-levels of government, such as states, regions, municipalities and local governments, provide an interesting lens through which to view austerity for a variety of reasons. The scale, scope and reach of such organisations tends to be significant in most countries and as such the impact on them of the consequences of the financial crisis is also large. Across OECD countries, such sub-levels of government account for about $31 \%$ of total government spending and $22 \%$ of tax revenues (Blochliger et al, 2010: 5). At the same time, administrative arrangements at this level differ across countries and it is therefore useful to explore whether similar or different reactions have occurred in response to the crisis and austerity period.

The detailed composition of 'local government' varies across countries and is largely dependent upon the federal or unitary nature of the country in question. There is also a wide difference in the numbers and sizes of local governments both within and across nation states. For example, Austria is a federal state consisting of 9 regions (Länder) and 2,100 local governments that enjoy relatively high political and functional autonomy and have an average population of around 3,000 inhabitants. England on the other hand is part of the unitary state of the United Kingdom and has no regions and only 353 local governments. English LGs have considerably higher populations than their Austrian counterparts (around 155,000 based on the current population estimates). Such differences provide interesting points of comparison between the chapters of this book.

Notwithstanding the differences across countries in the size and composition of their local governments, it is fair to say that in each case, local governments have a direct impact on the lives of local people, the functioning of local economies and in the delivery of national governments' policies. They are often the focal point for local economic development, public health and wellbeing, security and education.

They are also the beneficiaries of large scale transfer payments form national/higher levels of governments, something which they usually have little control over but are often reliant on. Austerity responses at the national level have filtered down to the local level in various degrees, impacting upon the resources available to deliver services and subsequently impacting on the availability of services to local communities. 
In parallel with this, local governments are usually able to raise their own resources through local taxation and other revenue in the form of fees and charges. The proportion of these resources and the degree of autonomy over these own sources of income varies across nation states, and over time, and represents an interesting juxtaposition from which to compare the ways in which responses to the crisis were managed at a local level.

\section{The structure of the book}

The remaining chapters of the book are structured as follows. In chapters 2 to 12 the experiences of 11 countries during the austerity period are examined. These chapters cover Europe, the USA, South America and Australia. The countries covered by the respective chapters are as follows:

- Australia

- Austria

- Brazil

- England

- France

- Germany

- Greece

- Italy

- The Netherlands

- Sweden

- USA

As such they cover a range of different structural forms, legislative requirements and cultural differences. They also reveal differences in the timings and impact of the crisis and austerity period, as well as the range of responses at both the national and local levels. Each chapter has been written by experienced academics 
in this field within their respective country and follows a similar structure, except where the national context requires a different approach (e.g. Australia). Generally speaking, within each chapter, the context of local government is explored in relation to the impact the financial crisis and austerity had within each country. There is an overview provided of the methodology employed in each case that while similar, again varies sometimes due to individual country circumstances. Most of the country chapters focus on the fortunes of four local government cases that are summarised within each chapter before a discussion of their similarities and differences and their capacities. Each country chapter concludes by classifying types of resilience patterns that were evident within the cases.

Finally, we summarize the position across all the chapters and draw conclusions regarding the nature of financial resilience in an international context in response to austerity. This final chapter reveals some interesting and surprising comparisons across the 11 countries and identifies how this research stream can be developed further in future. In the final chapter, a synthesis and interpretation of the case studies are presented, which assists in (1) further developing and operationalizing the concept of governmental financial resilience, its components, as well as the different approaches to resilience and (2) capturing the related contextual and organizational explanatory variables. The identification of similar patterns and perceptions of resilience within different national contexts and, at the same time, the recognition of distinct configurations, point to the role of economic, institutional and organizational circumstances in affecting the relative effectiveness of approaches to resilience as well as models to measure it. Moreover, it highlights the boundaries of a universalistic approach in the description of responses to a global crisis. 


\section{References}

Altintas, Gulsun and Isabelle Royer. 2009. Renforcement de la résilience par un apprentissage post-crise: une étude longitudinale sur deux périodes de turbulence. M@n@gement 12(4): 266-293.

Anderies, J. (2006). Robustness, institutions, and large-scale change in social-ecological systems: the Hohokam of the Phoenix Basin. Journal of Institutional Economics, 2(02):133-155.

Anderies, J., Janssen, M., and Ostrom, E. (2004). A framework to analyze the robustness of social-ecological systems from an institutional perspective. Ecology and Society, 9(1):18.

Anderies, J., Rodriguez, A., Janssen, M., and Cifdaloz, O. (2007). Panaceas, uncertainty, and the robust control framework in sustainability science. Proceedings of the National Academy of Sciences, 104(39):15194

Andrews, Rhys, George A. Boyne, and Richard M. Walker. 2012. Overspending in Public Organizations: Does Strategic Management Matter? International Public Management Journal 15(1): 39-61.

Ates, A., Bititci, U., 2011. Change process: a key enabler for building resilient SMEs. International Journal of Production Research 49, 5601-5618.

Baker, David L. 2011. Local Government Cutback Budgeting. The Public Manager 40(1): 9-11.

Barbera C., Guarini E., Steccolini, I., 2016, "Italian Municipalities and the fiscal crisis: four strategies for muddling through", Financial Accountability and Management, 32(3): 335-61.

Behn, Robert D. 1980. Leadership for Cut-Back Management: The Use of Corporate Strategy. Public Administration Review 40(6): 613-620.

Béné, Christophe, Rachel Godfrey Wood, Andrew Newsham, and Mark Davies. 2012. Resilience: New Utopia or New Tyranny? Reflection about the Potentials and Limits of the Concept of Resilience in Relation to Vulnerability Reduction Programmes. IDS Working Paper No. 405. Institute of Development Studies, Brighton, UK.

Bhamra Ran, Dani Samir, and Burnard Kevin. 2011. Resilience: the concept, a literature review and future directions International. Journal of Production Research 49(18): 5375-93.

Blochliger, Hansjorg; Charbit, Claire; Pinero Campos, Jose Maria; and Vammalle, Camila. 2010. "Sub-Central Governments and the Economic Crisis." Paris. OECD Economics Department Working Papers No. 752.

Boin, Arjen. 2009. The New World of Crises and Crisis Management: Implications for Policymaking and Research. Review of Policy Research 26(4): 367-77.

Boin Arjen and 't Hart Paul (2003) Public Leadership in Times of Crisis: Mission Impossible? Public Administration Review, 63(5), 544-553.

Boin Arjen and 't Hart Paul (2010), Organising for Effective Emergency Management: Lessons from Research, The Australian Journal of Public Administration, vol. 69, no. 4, pp. 357-371

Boin Arjen, 't Hart Paul \& McConnell Allan (2009) Crisis exploitation: political and policy impacts of framing contests, Journal of European Public Policy, 16:1, 81-106, 
Boin Arjen and Lodge Martin (2016), Designing Resilient Institutions for Transboundary Crisis Management: A Time for Public Administration, Public Administration Vol. 94, No. 2, (289-298)

Boin, Arjen, and McConnel 2007. Preparing for Critical Infrastructure Breakdowns: The Limits of Crisis Management and the Need for Resilience. Journal of Contingencies and Crisis Management 15(1): 50-59.

Boin, Arjen, and Michel J. G. Van Eeten. 2013. The Resilient Organization. Public Management Review 15(3): 429-45.

Boyne, George A., and Kenneth J. Meier. 2009. Environmental Change, Human Resources and Organizational Turnaround. Journal of Management Studies 46(5): 835-863.

Bozeman, Barry. 2010. Hard Lessons from Hard Times: Reconsidering and Reorienting the "Management Decline" Literature. Public Administration Review 70(4): 557-63.

Bracci, Enrico. Humphrey Christopher. Moll, Jodie. Steccolini, lleana. (2015) "Public sector accounting, accountability and austerity: more than balancing the books?", Accounting, Auditing \& Accountability Journal, Vol. 28 Iss: 6, pp.878 - 908

Breen, Patrick M., and J. Marty Anderies. 2011. Resilience: A Literature Review. The Rockefeller Foundation. Accessed March 10, 2013.

Carmeli A, Markman GD. Capture, governance and resilience: strategy implications from the history of Rome. Strategic Management Journal 2011;32(3):322-41.

Davoudi, Simin, Elizabeth Brooks, and Abid Mehmood. 2013. "Evolutionary Resilience and Strategies for Climate Adaptation." Planning Practice and Research 28 (3): 307-22..

Erol O, Sauser BJ, Mansouri M. A framework for investigating into extended enterprise resilience. Enterprise Information Systems 2010;4(2):111-36

Fleming RS. Ensuring organizational resilience in time of crisis. Journal of Global Business Issues 2012;6 (1):31-4.

www.rockefellerfoundation.org/media/download/a63827c7-f22d-495c-a2ab-99447a8809ba

Cepiku, Denita, and Andrea Bonomi Savignon. 2012. Governing Cutback Management: Is There a Global Strategy for Public Administrations? International Journal of Public Sector Management 25(6/7): 428-36.

Comfort, Louise K. 2002. Managing Intergovernmental Responses to Terrorism and Other Extreme Events. Publius 32(4): 29-40.

Coutu, Diane L. 2002. How Resilience Works. Harvard Business Review 46-55. https://www.boyden.pt/mediafiles/attachments/7030.pdf.

Darnhofer, Ika. 2014. Resilience and why it matters for farm Management, European Review of Agricultural Economics 41(3): 461-84. doi:10.1093/erae/jbu012.

Dalziell, Erica P., and Sonia T. McManus. 2004. Resilience, Vulnerability and Adaptive Capacity; Implications for Systems Performance. International Forum for Engineering Decision Making (IFED), Switzerland. 
Accessed March 10, 2013.

http://ir.canterbury.ac.nz/bitstream/10092/2809/1/12593870_ResOrgs_IFED_dec04_EDSM.pdf.

Davoudi, Simin. 2012. Resilience: A Bridging Concept or a Dead End? Planning Theory and Practice 13(2): 299-333.

Davoudi, Simin, and Libby Porter (edited by). 2012. Applying the Resilience Perspective to Planning: Critical Thoughts from Theory and Practice. Interface. Planning Theory \& Practice 13(2): 299-333.

Dougherty, Michael J., and Kenneth A. Klase. 2009. Fiscal Retrenchment in State Budgeting: Revisiting Cutback Management in a New Era. International Journal of Public Administration 32(7): 593-619.

Greenwood, Royston. 1981. Fiscal Pressure and Local Government in England and Wales. In Big Government in Hard Times, edited by Christopher Hood and Maurice Wright, 77-99. Wiley-Blackwell: Oxford.

Grossi Giuseppe and Cepiku Denita (2014) Editorial, Public Money \& Management, 34:2, 79-81

Gunderson, Lance H., and Crawford S. Holling (Eds.). 2002. Panarchy: understanding transformations in human and natural systems. Washington, D.C.: Island Press.

Hamel, Gary V., and Liisa Valikangas. 2003. The quest for resilience. Harvard Business Review 81(9): 52-63. http://rhesilience.com/blog/wp-content/uploads/2012/07/23HBRQuestforResilience-gary-hamel.pdf.

Head Brian W. and Alford John (2015), Wicked Problems: Implications for Public Policy and Management, Administration \& Society 2015, Vol. 47(6) 711-739

Heald David and Hodges Ron (2015), Will 'austerity' be a critical juncture in European public sector financial reporting? Accounting, Auditing and Accountability Journal, Vol 28 Iss 6 pp 1 - 31

Hendrick, Rebecca. 2004. Assessing and Measuring the Fiscal Health of Local Governments:

Focus on Chicago Suburban Municipalities. Urban Affairs Review 40(1): 78-114.

Hendrick, Rebecca. 2006. The Role of Slack in Local Government Finances. Public Budgeting and Finance 26(1): 14-46.

Hendrick, Rebecca. 2011. Managing the Fiscal Metropolis: The Financial Policies, Practices, and Health of Suburban Municipalities. Washington, DC: Georgetown University Press.

Hodges, R., Lapsley, I., 2016. A Private Sector Failure, a Public Sector Crisis - Reflections on the Great Recession. Financial Accountability and Management, 32(3): 265-280

Holling, C. S. (1986). The resilience of terrestrial ecosystems: Local surprise and global change. In W. C. Clark \& R. E. Munn (Eds.), Sustainable development of the biosphere (pp. 292-320). Cambridge, UK: Cambridge University Press

Holling, Crawford S. 1973. Resilience and Stability of Ecological Systems. Annual Review of Ecology and Systematics 4: 1-23. DOI: 10.1146/annurev.es.04.110173.000245.

Hood, Christopher. 1991. A Public Management for All Seasons? Public Administration 69: 3-19. 
Hood, Christopher and Maurice Wright. 1981. From Decrementalism to Quantum Cuts? In Big Government in Hard Times, edited by Christopher Hood and Maurice Wright, 199-227. Wiley-Blackwell: Oxford.

Huy, Quy Nguyen, and Henry Mintzberg 2003. The rhythm of change. MIT Sloan Management Review 44(4): 79-84. URL: http://vdonnell.pbworks.com/f/Rhythm+of+Change.pdf.

Janssen, M. and Anderies, J. (2007). Robustness trade-offs in social-ecological systems. International journal of the commons, 1(1):43-66.

Janssen, M., Anderies, J., and Ostrom, E. (2007). Robustness of social-ecological systems to spatial and temporal variability. Society \& Natural Resources, 20(4):307-322

Manouni Limnios et. al. 2014 The Resilience Architecture Framework: Four organizational archetypes, in European Management Journal (2014), 32, 104-116

Keck, Markus, and Patrick Skadapolrak. 2013. What is social resilience? Lessons learned and ways forward. Erdkunde 67: 5-19.

Kendra, J. M., \& Wachtendorf, T. (2003). Elements of Resilience after the World Trade Center Disaster: Reconstituting New York City's Emergency Operations Centre. Disasters, 27(1), 37-53.Kickert Walter (2012), State Responses to the Fiscal Crisis in Britain, Germany and the Netherlands, Public Management Review, 14:3, 299-309

Klase, Kenneth A. 2011. The Intersection of Flexible Budgeting and Cutback Management: Factors Affecting the Responses of Selected States to Recent Economic Recessions. Public Finance and Management 11(2): 197-230.

Kloha, Philip, Carol S. Weissert, and Robert Kleine. 2005. Developing and Testing a Composite Model to Predict Local Fiscal Distress. Public Administration Review 65(3): 313-23.

Leach, M. 2008. Re-framing Resilience: A Symposium Report. Brighton. STEPS Centre.

Lengnick-Hall, C. A., Beck, T. E., \& Lengnick-Hall, M. L. (2011). Developing a capacity for organizational resilience through strategic human resource management. Human Resource Management Review, 21(3), 243-255.

Linnenluecke, M. K., and a. Griffiths. 2013. “The 2009 Victorian Bushfires: A Multilevel Perspective Levine, Charles H. 1978. Organizational Decline and Cutback Management. Public Administration Review 38(4): 316-25.

Levine, Charles H. 1979. More on Cutback Management: Hard Questions for Hard Times. Public Administration Review 39(2): 179-83

Levine, Charles H., and Paul L. Posner. 1981. Centralizing Effects of Austerity on the Intergovernmental System. Political Science Quarterly 96(1): 67-85.

on Organizational Risk and Resilience." Organization \& Environment 26 (4): 386-411.

doi:10.1177/1086026613508126.

Linnenluecke, M., \& Griffiths, A. (2010). Beyond adaptation: Resilience for business in light of climate change and weather extremes. Business \& Society, 49(3), 477-511 
Lodge Martin and Hood Christopher (2012) Into an Age of Multiple Austerities? Public Management and Public Service Bargains across OECD Countries, Governance: An International Journal of Policy,

Administration, and Institutions, Vol. 25, No. 1, (pp. 79-101).

Maguire, Brigit, and Sophie Cartwright. 2008. Assessing a Community's Capacity to Manage Change: A Resilience Approach to Social Assessment. Australia, Social Sciences Program, Bureau of Rural Sciences. Accessed March 9, 2013. http://www.tba.co.nz/tba-eq/Resilience_approach.pdf

Mallak, L. (1998). Putting organizational resilience to work. Indus- trial Management, 40(6), 8-13.

Maher, Craig S., and Steven C. Deller. 2010. Measuring Municipal Fiscal Condition: Do Objective Measures of Fiscal Health Relate to Subjective Measures? Journal of Public Budgeting, Accounting \& Financial Management 23(3): 427-50.

Martin-Breen, Patrick M., and J. Marty Anderies. 2011. Resilience: A Literature Review. The Rockefeller Foundation. Accessed March 10, 2013

Martin, Ron, and Peter Sunley. 2006. Path dependence and regional economic evolution. Journal of Economic Geography 6: 395-437.

McConnell Allan (2003) Overview: Crisis Management, Influences, Responses and Evaluation, Parliamentary Affairs, 56 (2003): 393-409.

McManus, Sonia, Erica Seville, Dave Brunsdon, and John Vargo. 2007. Resilience Management. A Framework for Assessing and Improving the Resilience of Organizations.

Meier, Kenneth J., and Laurence J. O'Toole Jr. 2009. The Dog that Didn't Bark: How Public Managers Handle Environmental Shocks. Public Administration 87(3): 485-502.

Meier, Kenneth J., Laurence J. O'Toole Jr., and Alisa Hicklin. 2010. I've Seen Fire and I've Seen Rain: Public Management and Performance after a Natural Disaster. Administration and Society 20(10): 1-25.

Meyer, Alan D. 1982. Adapting to Environmental Jolts. Administrative Science Quarterly 27(4): 515-537.

Nelson, Donald R., W. Neil Adger, and Katrina Brown. 2007. Adaptation to Environmental Change:

Contributions of a Resilience Framework. Annual Review of Environment and Resources 32: 395-419.

O'Toole, Laurence J. and Kenneth J. Meier. 2010. In Defense of Bureaucracy. Public managerial capacity, slack and the dampening of environmental shocks. Public Management Review 12(3): 341-361.

OECD-SBO (2011) Restoring Public Finances, Paris: OECD Publishing

Pain Adam, and Simon Levine. 2012. A Conceptual Analysis of Livelihoods and Resilience: Addressing the 'Insecurity of Agency', HPG Working Paper. Accessed March 25, 2013.

http://www.odi.org.uk/sites/odi.org.uk/files/odi-assets/publications-opinion-files/7928.pdf.

Pal, Rudrajeet, H??kan Torstensson, and Heikki Mattila. 2014. "Antecedents of Organizational Resilience in Economic Crises - An Empirical Study of Swedish Textile and Clothing SMEs." 
Pandey, Sanjay K. 2010. Cutback Management and the Paradox of Publicness. Public Administration Review 70(3): 564-571.

Peters B. Guy (2011) Governance responses to the fiscal crisis - comparative perspectives, Public Money \& Management, 31:1, 75-80

Peters B. Guy, J. Pierre and T. Randma-Liiv (2011), 'Global Financial Crisis, Public Administration and Governance. Do New Problems Require New Solutions?', Public Organization Review, Vol. 11,

No. 1, pp. 13-28.Pickett, Steward T.A., Mary L. Cadenasso, and J. Morgan Grove. 2004. Resilient Cities: Meaning, Models, and Metaphor for Integrating the Ecological, Socio-Economic, and Planning Realms. Landscape and Urban Planning 69(4): 369-84

Pike, Andy, Stuart Dawley, and John Tomaney. 2010. Resilience, Adaptation and Adaptability. Cambridge Journal of Regions, Economy and Society 3: 59-70. DOI:10.1093/cjres/rsq001

Raudla, Ringa, Riin Savi, Tiina Randma-Liiv. 2013. Literature review on cutback management, COCOPS deliverable 7.1. Accessed 12 December 2014, http://www.cocops.eu/wpcontent/uploads/2013/03/COCOPS_Deliverable_7_1.pdf.

Reid, Richard, and Linda C. Botterill. 2013. The Multiple Meanings of 'Resilience': An Overview of the Literature Reid. Australian Journal of Public Administration 72(1): 31-40.

Scorsone, Eric A., and Christine Plerhoples. 2010. Fiscal Stress and Cutback Management Amongst State and Local Governments: What Have We Learned and What Remains to be Learned? State and Local Government Review 42(2): 176-87.

Reinmoeller, P. and Baardwijk, N. (2005), The link between diversity and resilience. MIT Sloan Management Review, pp. 61-65

Reid, Richard, and Linda Courtenay Botterill. 2013. "The Multiple Meanings of 'Resilience': An Overview of the Literature." Australian Journal of Public Administration 72 (1): 31-40. doi:10.1111/1467-8500.12009.

Rosenthal, Uriel, Michael T. Charles, and Paul T. Hart. 1989. Coping With Crises: The Management of Disasters, Riots, and Terrorism. Hardcover, Sprngfield, IL: Charles C. Thomas.

Rosenthal, Uriel, Arjen Boin, Louise K. Comfort. 2001. The Changing World of Crises and Crisis Management. In Rosenthal, Uriel, Arjen Boin, Louise K. Comfort. Managing Crises- Threats, Dilemmas, Opportunities. Springfield, IL: Charles C. Thomas, pp. 5-27

Seville, E., 2009. Resilience: great concept . . . but what does it mean for organisations? Community Resilience: Research, planning and civil defence emergency management. Volume 22. New Zealand Ministry of Civil Defence \& Emergency Management

Shaw, Keith. 2012. "The Rise of the Resilient Local Authority?" Local Government Studies Volume: 38 (3): 281-300.

Teixeira, Eduardo de Oliveira, and William B. Werther. 2013. "Resilience: Continuous Renewal of Competitive Advantages." Business Horizons 56 (3). "Kelley School of Business, Indiana University": 333-42. doi:10.1016/j.bushor.2013.01.009. 
Skertich, Robert L., David E. A. Johnson, and Louise K. Comfort. 2013. A Bad Time for Disaster: Economic Stress and Disaster Resilience, Administration and Society 45(32): 145- 66

Scotti-Petrillo, Adriana, and David C. Prosperi. 2011. "Metaphors from the Resilience Literature: Guidance for Planners". In Schrenk, Manfred, Vasily V. Popovich, Peter Zeile, Pietro Elisei. REAL CORP 2011. Re-mixing the city. Towards sustainability and resilience, pp. 601-611, Tagungsband. Accessed June 25, 2013.

http://www.corp.at/archive/CORP2011_99.pdf.

Sacco, John F., Odd Stalebrink, Paul L. Posner. 2011. Introduction to the Symposium on Flexible Budgeting. Public Finance and Management 11(2): 86-92.

Scorsone, Eric A., and Christine Plerhoples. 2010. Fiscal Stress and Cutback Management Amongst State and Local Governments: What Have We Learned and What Remains to be Learned? State and Local Government Review 42(2):

Shaw, Keith. 2012. The Rise of the Resilient Local Authority? Local Government Studies 38(3): 281-300.

Schick, Allen. 1980. Congress and Money. Budgeting, Spending, and Taxing. Washington, D.C.: Urban Institute.

Steccolini, I., Barbera, C. and Jones, M. (2015), Governmental Financial Resilience Under Austerity: The Case of English Local Authorities, CIMA Executive Summary Report, Volume 11, Issue 3

Sutcliffe, Kathleen M., and Timothy J. Vogus. 2003. Organizing for resilience, in Positive Organizational Scholarship: Foundations of a New Discipline, edited by Kim S. Cameron, Jane E. Dutton, and Robert E. Quinn, 94-121. Berrett-Koehler: San Francisco, CA.

Trussel, John M., and Patricia A. Patrick. 2009. A Predictive Model of Fiscal Distress in Local Governments. Journal of Public Budgeting, Accounting \& Financial Management 21(4): 578-61.

Vale, Lawrence J., and Thomas J. Campanella. 2005. The Resilient City: How Modern Cities Recover from Disaster. New York: Oxford University Press.

Vickers, Margaret H. and Alexander Kouzmin. 2001. 'Resilience' in organizational actors and rearticulating 'voice': towards a humanistic critique of new public management. Public Management Review 3(1): 95119.

Weick, Karl E. Sutcliffe Kathleen M. and Obstfeld David (1999), Organizing for High Reliability: International Journal of Production Economics 147 (PART B). Elsevier: 410-28.

Vale, L.J. \& Campanella, T.J. (2005) The Resilient City: How Modern Cities Recover from Disaster (New York, Oxford University Press)

Välikangas and Romme 2012

Walker, V. Reid, Brian Walker, and David Salt. 2006. Resilience Thinking: Sustaining Ecosystems and People in a Changing World. Washington, D.C.: Island Press 
Whitman et. al. (2013) Short-form version of the Benchmark Resilience Tool (BRT-53), Measuring Business Excellence, 17, 3, p. 1-14

Processes of Collective Mindfulness in R.S. Sutton and B.M. Staw (eds), Research in Organizational Behavior, Volume 1 (Stanford: Jai Press, 1999), pp. 81-123.

West, Jonathan P., and Stephen E. Condrey. 2011. Municipal Government Strategies for Controlling Personnel Costs During the Fiscal Storm. Journal of Public Budgeting, Accounting and Financial Management 23(3): 395-426.

Wildavsky, Aaron B. 1988. The New Politics of the Budgetary Process. Glenwiew, IL: Scott, Foresman.

Wolman Harold (2014), National Fiscal Policy and Local Government during the Economic Crisis, Urban Policy Paper Series, the German Marshall Fund of the United States, Washington DC

Wukich, Clayton. 2013. Searching for Resilience. Journal of Public Administration Research and Theory Advance. July 11. Book Review. 